\title{
Q-and-A: COVID-19's effects on food systems, youth development programs and nutrition
}

\author{
An interview with UC Cooperative Extension experts about the effect of the coronavirus pandemic \\ on food systems, youth development and nutrition.
}
- hrough the COVID-19 pandemic, UC Agriculture and Natural Resources (UC ANR) has continued to work to safeguard abundant and healthy food for all Californians, promote healthy people and communities, build skills needed in the workforce and help to develop an inclusive and equitable society. For insights into how the pandemic is affecting life in California and UC ANR's programs in these areas, California Agriculture spoke with UC ANR experts in the fields of food systems, positive youth development and nutrition. The edited conversations appear below.

\section{Gail Feenstra, Deputy Director of the Sustainable Agriculture Research and Education Program (a UC ANR statewide program) and Food and Society Coordinator for the Agricultural Sustainability Institute at UC Davis}

California Agriculture: Your expertise lies partly in local and regional food systems, giving you an overview of issues from the farm to distribution channels and all the way to communities and consumers. In broad

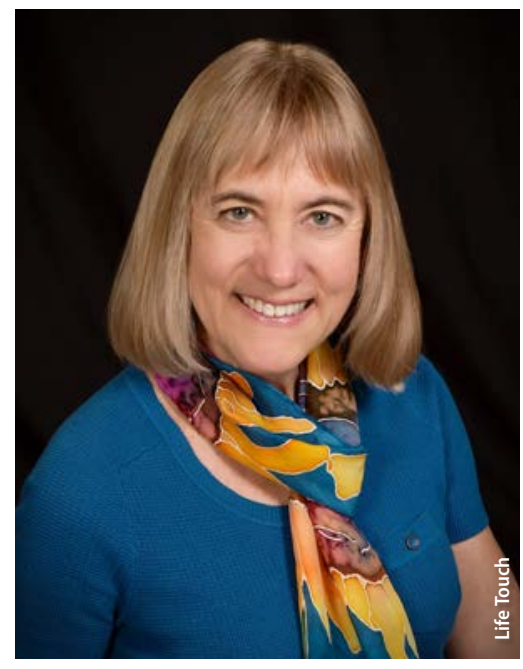

Gail Feenstra terms, how would you say the coronavirus has affected the food system so far?

Gail Feenstra: We've seen some major pivoting of activity. For businesses across the supply chain, things were really chaotic in the early days. Things have gotten a little calmer now, but there's some good and bad news. The good news is we're not seeing the grocery store shortages and hoarding like we were in the early days. On the negative front, there are plenty of farmers still struggling to figure out what their markets are going to look like. Some of them have pivoted to new markets and others have not been successful in finding markets. Institutional markets have suffered - schools, corporate cafeterias and obviously restaurants. On the other hand, certain other markets have ramped up. Everybody wants a community-supported agriculture or subscription box, which is a box of locally grown produce that people pay for in advance.

California Agriculture: How about the rest of the food chain? How has the pandemic affected distributors?

Gail Feenstra: Some suppliers are scrambling. For some, it's probably less of an issue than for the producers. People still need to eat, so if they're not going to restaurants, they've got to get their food from a grocery store. If you look at the U.S. population, before COVID, people got close to $50 \%$ of their food outside the home. And that changed pretty drastically. People are cooking more, gardening more. They are also supporting takeout to some extent.

Another issue I'd like to bring up, a part of the supply chain often forgotten, is farmworkers. They are at the highest risk. They're putting their lives on the line every day. According to a recent study coordinated by the California Institute for Rural Studies, agricultural workers in Monterey County were three times more likely to become infected by COVID-19 than persons employed in nonagricultural industries. And farmworkers are not getting enough of what they need to stay healthy. Often they're people of color, and do not have access to adequate health care, nutritious food and housing. Also, if farms go under, they lose their jobs.

California Agriculture: Another issue you're involved in is sustainable agriculture. I'm wondering what effect the virus is having on efforts toward environmental, economic and social sustainability. Can sustainability efforts proceed amid the coronavirus, or is a lot of that just stopped for now?

Gail Feenstra: Well, some of the social issues, in terms of credit and access to resources for small and midscale farmers and workers and processors - that part is not going as well as it could. One of the things that this coronavirus did was unmask some of the things in the food system that were already problematic.

It is showing how we are deficient in some areas for example, infrastructure in regional food systems, 
especially infrastructure that would benefit mid-scale farmers and ranchers. It's just not available - for example, facilities for processing beef or lamb or pork, so that ranchers don't have to drive for a day to get to a processing facility. There just isn't enough that caters to regional or smaller-scale ranchers. The system is not built for that.

California Agriculture: Is there anything I should have asked but haven't?

Gail Feenstra: One important issue is building our understanding of farmers and other people in the food system who are Black, indigenous and people of color.
We need to be focusing on them because they are the ones that are really in need of resources. And it's not just about white people helping them. It's more about facilitating those groups building their own leadership structures and power base so that they can begin to participate more fully in the food system along with everybody else. For example, I'm thinking of the Hmong and Vietnamese farmers in the southern part of the state. There are a lot of Hispanic growers too. And then there are the native tribes. And I think, as Cooperative Extension, we need to be attuned to these groups more and figure out how we can work with them to build a resilient food system that also works for them.

\section{Fe Moncloa, 4-H Youth Development Advisor in Santa Clara County}

California Agriculture: Could you explain what your work in positive youth development consists of in normal times, when there's no pandemic going on?

Fe Moncloa: For me, positive youth development in Santa Clara County mostly means supporting the staff who provide oversight and management of the 4-H club program and supporting staff who work in partnership with schools and with community nonprofit organizations.

California Agriculture: What does actual program delivery to the kids look like?

Fe Moncloa: I'll focus on one part that most people are not familiar with. At a school in our area, I work with teenagers who are new immigrants to the United States and either just arrived or have lived in the United States for a year or two, tops. They are predominantly Spanish speakers and they're learning English. I teach computer science concepts to teenagers who have never, ever learned anything around computational thinking. After they learn it, I ask them to teach it to younger children. They do incredibly well. My staff member in that same school trains seventh and eighth graders in a curriculum called Youth Experiencing Science. It's a well-known curriculum that was developed in California years and years ago, and we continue to use it. It was written specially so that teenagers could teach it to younger children. My staff invests about 20 hours in training these teenagers to teach the curriculum to kids from kindergarten through third grade.

California Agriculture: How has the pandemic changed things - both for you and for the work you're trying to do in your area?

Fe Moncloa: When shelter-in-place started, I was personally in disarray, so I figured that my volunteers and families were also in disarray. So I waited a couple of weeks and then convened a meeting with all the project leaders. We gave them some tips on how to engage children via online learning and had a brainstorming session. Then we created Google documents to keep track of who was doing what regarding the 50 or so projects that were happening in the club program before shelter-in-place. We ended up continuing 18 of them - basically, the ones that were possible to deliver remotely.

A lot of our volunteers found themselves working from home, or running their own businesses from home, and taking care of their children at the same time. In addition to that, we were asking them to teach a project. That's the reality of volunteerism right now. In my first meeting with volunteers, I told them there was no pressure - that if they had a sliver of time to support young people, my staff and I were here to support them. Out of the 18 projects that happened, I would say that half of them are led

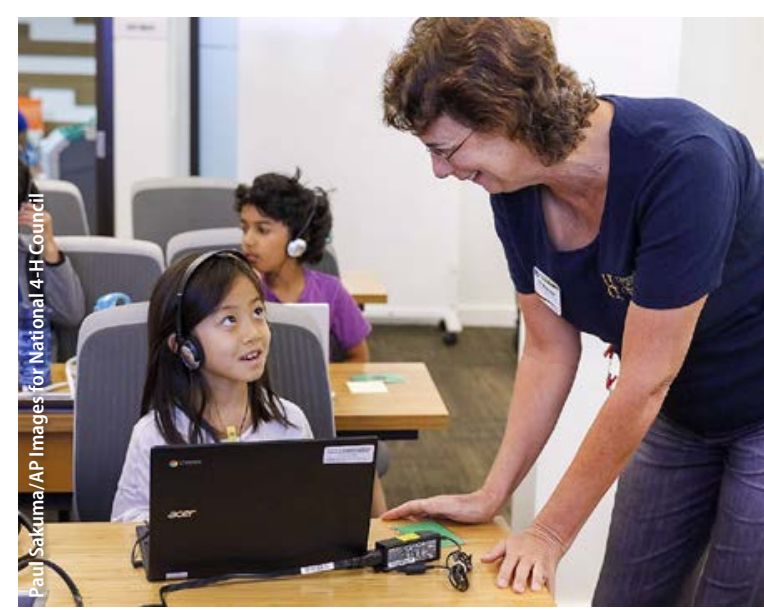

Fe Moncloa by teenagers. One thing that has been crucial in the club program is staying connected. Because that's what kids are craving right now.

California Agriculture: Obviously the coronavirus is a problem in a lot of ways. But does it in any sense represent an opportunity for youth development? Is it something you can make a virtue from?

Fe Moncloa: Well, one opportunity I see is that young people are learning new skills, like video-making — it's something they may have done in the past, but just for fun. Now they're getting really good at it. They're learning about lighting and sound. In the typical $4-\mathrm{H}$ way, we ask them to make a video, and after they make it, we say "Well, you might want to consider this and this, and change this and that." So they're learning as they're doing it, which is our model. The other thing I have seen is teenagers learning how to engage younger children in fun, interactive ways via Zoom. 
